\title{
Indole Degradation in a Model System and in Poultry Manure by Acinetobacter spp.
}

\author{
Tujuba Ayele Tesso ${ }^{1,2}$ and Guohua Liu ${ }^{1, *}$ \\ 1 The Key Laboratory of Feed Biotechnology of Ministry of Agriculture, National Engineering Research Center \\ of Biological Feed, Feed Research Institute, Chinese Academy of Agricultural Sciences, No. 12, \\ Zhong-guan-cun Nandajie, Haidian, Beijing 100081, China; tuj2001@gmail.com \\ 2 Department of Biology, Faculty of Natural Sciences, Mettu University, P. O. Box 318 Mettu, Ethiopia \\ * Correspondence: liuguohua@caas.cn
}

Received: 28 February 2019; Accepted: 15 April 2019; Published: 18 April 2019

\begin{abstract}
Indole degradation in a model system and in poultry manure was studied using an enrichment culture of two Acinetobacter species; Acinetobacter toweneri NTA1-2A and Acinetobacter guillouiae TAT1-6A. Degradation of indole was quantified using reverse phase high performance liquid chromatography (HPLC). The two strains were capable of degrading initial concentrations of indole ranging from $58.58-300 \mathrm{mg} / \mathrm{L}$. The degradation efficiency was $66.36 \%$ (NTA1-2A), 94.87\% (TAT1-6A), and $96.00 \%$ (mix) in 6 days when the initial concentration $<300 \mathrm{mg} / \mathrm{L}$. The strains were tested for enzymatic activity using $120 \mathrm{mg} / \mathrm{L}$ indole. The enzyme extracts of NTA1-2A and TAT1-6A from culture medium degraded indole completely, and no appreciable change of indole concentration was witnessed in the control group. The NTA1-2A, TAT1-6A, and the mix of strains were also used for in vivo poultry manure fermentation and removed $78.67 \%, 83.28 \%$, and $83.70 \%$ of indole, respectively in $8 \mathrm{~d}$. The strains showed a statistically significant difference $(p<0.05)$ in indole removal efficiency compared with the control, but no significant difference between the two strains and the mix in indole removal capacity. We concluded that $A$. toweneri NTA1-2A and A. guillouiae TAT1-6A are promising strains to remove indole and its derivatives to control the notorious odor in poultry and other livestock industries.
\end{abstract}

Keywords: Acinetobacter; biodegradation; indole; fermentation; manure

\section{Introduction}

Indole is a common metabolite of tryptophan formed in the rumen and colon of monogastric animals [1-4]. It is one of the major recalcitrant odorant compounds in livestock and poultry industries [5] that are considered environmental pollutants [6]. It is produced in animal intestines by tryptophan degradation [1,2]. Indole is also industrially produced for various purposes such as pharmaceuticals, cosmetics, pesticides, disinfectants, agrochemicals, and dyestuffs $[7,8]$, and then released into the environment, where it is often found in waste water, costal lagoons, and sediment. It is a typical nitrogen heterocyclic aromatic pollutant and extensively spread in industrial wastewater [9]. Indole contributes to the unpleasant odor of feces in mammals and birds, and are major pollutants affecting public health and livestock industries $[10,11]$. It can be absorbed into the blood and hemolyze bovine erythrocytes [12], is toxic to many microorganisms, and has a fairly broad bacteriostatic effect [13].

Previous studies used different physico-chemical and biological methods to remove indole from animal manure and waste water [14,15], however the challenge is still persistent and there is demand for an efficient and eco-friendly means of elimination. Microorganisms play a vital role in the removal of indolic compounds and its derivatives under aerobic and anaerobic conditions $[2,3,16-18]$. 
Sakamoto et al. [19] reported that indole was degraded aerobically by a bacterium isolated from tap water. Yin et al. [20] investigated aerobic degradation of indole using Pseudomonas aeruginosa Gs isolated from mangrove sediment. Under aerobic conditions, indole metabolism was generally initiated by oxidation of indole followed by heterocyclic ring cleavage [21]. Under anaerobic conditions indole could be metabolized to form methane [22]. Bak and Widdel [1] isolated a sulfate reducing bacterium, Desulfobacterium indolicum from marine sediments which used indole as its sole carbon source. Bacterial consortia also degrade indole under anaerobic and denitrifying conditions [23-25]. Gu and Berry [26,27] studied the degradation of indole and 3-methylindole by an indole degrading methanogenic consortium enriched from sewage sludge. Microorganisms either mineralized indolic compounds completely [28] or transformed into other compounds in the presence of an additional carbon source [18,29]. Indole biotransformation has also been studied in different bacterial strains [30,31]. For instance, two phenol-degrading strains, Pseudomonas sp. PI1 and Acinetobacter sp. PI2 isolated from activated sludge could biosynthesis indigo [32]. Qu et al. [33] reported transformation of indole to indigo using a biphenyl dioxygenase enzyme cloned from Dyella ginsengisoli L-4 and heterologously expressed in Escherichia coli (DE3). Co-metabolism of indole in glucose and nitrate was also reported in the mold Aspergillus niger [2]. Aerobic degradation of organic pollutants using microbes is faster and more efficient compared with anaerobic methods [34].

Several bacteria degrading indole were isolated and studied, but only a few indole-degrading Acinetobacter strains were reported. For instance, many Acinetobacter have been reported in the degradation of $n$-alkane and long chain hydrocarbons [35,36], and aromatic compounds such as phenol and chlorophenol [37-40]. Recently indole degradation has been reported in genus Acinetobacter by different researchers [41-44]. Even though some work has been done on indole biodegradation by microorganisms from different environments such as marine and mangrove sediments, and others $[20,28,45,46]$, limited work has been done on the biodegradation of indole in the poultry industry.

The strains of Acinetobacter used in this experiment therefore degraded indole efficiently under aerobic conditions. In this study, two Acinetobacter strains previously isolated from chicken manure and acclimated in 3-methylindole [47] were used to degrade indole, and demonstrated strong ability of indole removal from culture medium and poultry manure. Hence, this study evaluates in vivo and in vitro degradation of indole under different conditions using Acinetobacter toweneri NTA1-2A and Acinetobacter guillouiae TAT1-6A strains.

\section{Materials and Methods}

\subsection{Source of Microorganisms}

Bacterial isolates of Acinetobacter toweneri NTA1-2A and Acinetobacter guillouiae TAT1-6A, previously isolated from poultry manure were used. The strains have been preserved in the China General Microbiological Culture Collection Center (CGMCC) and the preservation numbers are CGMCC No. 14001 and 14002, respectively.

\subsection{Medium Conditions and Bacteria Growth}

A minimal salt medium (MSM) containing $150 \mathrm{~mL}$ of a solution (per $\mathrm{L}$ of distilled water) of $0.80 \mathrm{~g} \mathrm{~K}_{2} \mathrm{HPO}_{4}, 0.20 \mathrm{~g} \mathrm{KH}_{2} \mathrm{PO}_{4}, 0.05 \mathrm{~g} \mathrm{CaCl}_{2}, 0.5 \mathrm{~g} \mathrm{MgCl}_{2}, 0.01 \mathrm{~g} \mathrm{FeCl}_{2}, 1.0 \mathrm{~g}\left(\mathrm{NH}_{4}\right)_{2} \mathrm{SO}_{4}, 5.0 \mathrm{~g} \mathrm{NaCl}$, and $1.0 \mathrm{~g}$ yeast extract (Difco, Detroit, MI, USA), amended with indole in a $250 \mathrm{~mL}$ Erlenmeyer flask was prepared for the enrichment and isolation of aerobic indole degrading bacteria [48]. The $\mathrm{pH}$ was adjusted to 6 using $1 \mathrm{~mol} / \mathrm{L}$ solution of $\mathrm{NaOH}$ and $\mathrm{HCl}$ before sterilization. Pre-sterilized MSM at $121^{\circ} \mathrm{C}$ for $20 \mathrm{~min}$ was amended with $58.58 \mathrm{mg} / \mathrm{L}(0.5 \mathrm{mM})$. Indole was dissolved with sterilized hot water $\left(50 \mathrm{~mL}, 40^{\circ} \mathrm{C}\right)$; filtered with $0.22 \mu \mathrm{m}$ pore-size polytetrafluoroethylene (PTFE) membrane syringe filter and used as the source of carbon and energy for the bacteria during the degradation experiment. The bacterial isolates were grown on agar plates amended with $58.58 \mathrm{mg} / \mathrm{L}(0.5 \mathrm{mM})$ 
indole and incubated for $36 \mathrm{~h}$. The strains were activated using yeast extract $(1 \mathrm{~g} / \mathrm{L})$ with MSM for $24 \mathrm{~h}$. The enrichment culture was started by transferring $100 \mu \mathrm{L}$ inoculants to sterile MSM amended with $58.58 \mathrm{mg} / \mathrm{L}(0.5 \mathrm{mM})$ of indole and was gradually increased.

\subsection{Indole Degradation by NTA1-2A and TAT1-6A}

Individual colonies of pure culture from the agar plates were selected for inoculation of pre-sterilized MSM containing $1.0 \mathrm{~g} / \mathrm{L}$ yeast extract (Difco, Detroit, MI, USA) in Erlenmeyer flasks which were incubated on a shaking incubator operating at $140 \mathrm{rpm}$ and $31^{\circ} \mathrm{C}$ for $24 \mathrm{~h}$. To start the biodegradation experiment, $100 \mu \mathrm{L}$ active cultures was used to inoculate pre-sterilized MSM containing indole, and the initial concentration was increased gradually from 58.58 to $351.45 \mathrm{mg} / \mathrm{L}$ (0.5 to $3.0 \mathrm{mM}$ ). Each treatment was conducted in triplicate, with both uninoculated flasks and flasks without indole serving as controls.

\subsection{Factors Affecting Indole Degradation}

Temperature (T) and $\mathrm{pH}$ were used as single factors to study the characteristics of the strains NTA1-2A and TAT1-6A. All experiments were carried out under sterile conditions. For temperature, the culture temperature was set to $25,28,31,34$ and $37^{\circ} \mathrm{C}$ separately with constant $\mathrm{pH}$ of 6 . For the $\mathrm{pH}$ factor, the initial $\mathrm{pH}$ was adjusted to 5, 6, 7, 8 and 9, respectively using $1 \mathrm{~mol} / \mathrm{L} \mathrm{HCl}$ or $1 \mathrm{~mol} / \mathrm{L} \mathrm{NaOH}$ solution at $31^{\circ} \mathrm{C}$ and $140 \mathrm{rpm}$ shaking speed. The initial concentration of indole remains constant during both factors.

\subsection{Enzyme Activity Test for Indole Metabolism}

The strains NTA1-2A and TAT1-6A were tested for enzymatic activity of indole degradation. The culture media of the strains were filtered, and the supernatant fluid was used to incubate $120 \mathrm{mg} / \mathrm{L}$ of indole for $48 \mathrm{~h}$ at $31^{\circ} \mathrm{C}$. Concentration of indole was determined after incubation at $31^{\circ} \mathrm{C}$ for $48 \mathrm{~h}$.

\subsection{Poultry Manure Fermentation Experiment}

Poultry manure was collected from the Chinese Academy of Agricultural Sciences (CAAS) breeding farm and fermented for eight days using the two strains. In this experiment, $4 \mathrm{~kg}$ of poultry manure was added to $10 \mathrm{~L}$ buckets in triplicate and fermented using NTA1-2A $\left(10^{6}\right.$ colony forming unit $/ \mathrm{mL})$ and TAT1-6A ( $10^{7}$ colony forming unit $\left./ \mathrm{mL}\right)$, which was added to each sample and mixed well. Non-inoculated manure was used as a control for each treatment. Samples were collected before treatment and during the fermentation every $2 \mathrm{~d}$ and stored at $-21^{\circ} \mathrm{C}$ in plastic bags. One gram of each sample was mixed with $3 \mathrm{~mL}$ of methanol, heated in a water bath for $20 \mathrm{~min}$ at $40^{\circ} \mathrm{C}$ and vortex-mixed every $5 \mathrm{~min}$. Finally, the sample was placed in the refrigerator at $-21^{\circ} \mathrm{C}$ for $15 \mathrm{~min}$ to accelerate precipitation speed. The supernatant was carefully collected and prepared for HPLC analysis by centrifuging at $12,000 \mathrm{rpm}$ for $10 \mathrm{~min}$, and filtering onto $0.22 \mu \mathrm{L}$ pore-sized syringe filter membrane. The samples were stored at $4{ }^{\circ} \mathrm{C}$ and analyzed using HPLC for indole concentrations using standard indole (Shanghai Macklin Biochemical Co. Ltd., Shanghai, China).

\subsection{Sample Preparation for HPLC Analysis}

An Agilent C18 column (Agilent Technologies, Inc., Santa Clara, CA, USA), $250 \mathrm{~mm} \times 4.6 \mathrm{~mm}$, with a particle size of $5 \mu \mathrm{m}$ was used for high performance liquid chromatography (Shimadzu LC-15C, Kyoto, Japan). The mobile phase contained 1\% acetic acid and methanol at a ratio of 50:50 (v:v). The flow rate, injection volume, detection wavelength and column temperature were $0.6 \mathrm{~mL} / \mathrm{min}$, $20 \mu \mathrm{L}, 260 \mathrm{~nm}$ and $30^{\circ} \mathrm{C}$, respectively. In preparation for HPLC analysis, $2 \mathrm{~mL}$ of culture samples were collected and prepared by centrifuging $(8000 \times g)$ (Eppendorf $5427 \mathrm{R}$ Centrifuge, Eppendorf AG, Hamburg, Germany) and filtering through $0.22 \mu \mathrm{m}$ pore-size PTFE membrane syringe filters. Quantities of the analytes were examined from a standard curve prepared using standard indole 
(Shanghai Macklin Biochemical Co. Ltd., Shanghai, China). The quantity of indole in each sample was determined in $\mathrm{mg} / \mathrm{kg}$. The recovered quantity was also calculated as the percentage value with respect to the total concentration of indole added in the medium.

\subsection{Statistical Analysis}

The results obtained were presented as mean values with standard deviation of triplicate assays. Simple linear regressions for indole standard solutions with different gradient concentrations and the growth of Acinetobacter strains in the MSM with indole were calculated using Microsoft Excel 2010. The data were subjected to one-way variance analysis (ANOVA). Statistical Package for the Social Sciences (SPSS) Version 20 (IBM Corp., Armonk, NY, USA) was used to analyze the difference between treatment groups. Post hoc analysis was carried out using least significance difference (LSD) test for comparison of means at $p<0.05$ significance level. Sigma-plot (Version 12.5) was used to sketch graphs.

\section{Results}

\subsection{Indole Removal Efficiency}

Indole degradation efficacy tests of NTA1-2A, TAT1-6A, and a mix of the two strains at different initial concentrations of $58.58,117.15,175.73,234.30,292.88,351.45 \mathrm{mg} / \mathrm{L}$ were inoculated with $100 \mu \mathrm{L}$ of the strains and incubated for 6 days under aerobic conditions. Samples $(2 \mathrm{~mL})$ were collected every $2 \mathrm{~d}$ to determine indole concentration by HPLC. Indole degradation was performed by the bacterial strains in the culture media amended with different concentrations. The degradation efficiency (\%) was $66.36 \%, 94.87 \%$, and $96.0 \%$ respectively in NTA1-2A, TAT1-6A, and a mix of strains within 6 days at $2.5 \mathrm{mM}(292.88 \mathrm{mg} / \mathrm{L})$ concentration (Table 1). When indole concentration was $3 \mathrm{mM}(351.45 \mathrm{mg} / \mathrm{L})$, the strains degraded only $26.43 \%$ (NTA1-2A), $25.29 \%$ (TAT1-6A), and $29.0 \%$ (mix).

Table 1. Indole degradation ability of NTA1-2A, TAT1-6A, and a mix incubated for 6 days. Values are the mean \pm SD of triplicate assays.

\begin{tabular}{|c|c|c|c|c|c|}
\hline \multirow[b]{2}{*}{$\mathrm{C}(\mathrm{mg} / \mathrm{L})$} & \multirow[b]{2}{*}{$\begin{array}{l}\text { Incubation } \\
\text { Time (d) }\end{array}$} & \multicolumn{4}{|c|}{ Indole Removal Efficiency (\%) } \\
\hline & & NTA1-2A & TAT1-6A & Mix Strains & $p$-Value \\
\hline \multirow[t]{3}{*}{58.58} & 2 & $77.72 \pm 0.24^{\mathrm{a}}$ & $100 \pm 0.00^{b}$ & $100 \pm 0.00^{b}$ & 0.000 \\
\hline & 4 & $77.87 \pm 0.04^{\mathrm{a}}$ & $100 \pm 0.00^{b}$ & $100 \pm 0.00^{b}$ & 0.000 \\
\hline & 6 & $77.86 \pm 0.03^{a}$ & $100 \pm 0.00^{b}$ & $100 \pm 0.00^{b}$ & 0.000 \\
\hline \multirow[t]{3}{*}{117.15} & 2 & $88.64 \pm 0.05^{b}$ & $96.32 \pm 6.37^{\mathrm{a}}$ & $98.04 \pm 3.40^{\mathrm{a}}$ & 0.069 \\
\hline & 4 & $88.60 \pm 0.04^{a}$ & $100 \pm 0.00^{b}$ & $100 \pm 0.00^{b}$ & 0.000 \\
\hline & 6 & $88.61 \pm 0.14^{\mathrm{a}}$ & $100 \pm 0.00^{b}$ & $100 \pm 0.00^{b}$ & 0.000 \\
\hline \multirow[t]{3}{*}{175.73} & 2 & $91.89 \pm 0.10^{b}$ & $92.59 \pm 0.04^{b}$ & $94.67 \pm 2.08^{a}$ & 0.054 \\
\hline & 4 & $91.78 \pm 0.10^{b}$ & $92.61 \pm 0.0^{b}$ & $95.57 \pm 2.45^{\mathrm{a}}$ & 0.038 \\
\hline & 6 & $91.42 \pm 0.26^{\mathrm{a}}$ & $92.61 \pm 0.0^{\mathrm{a}}$ & $95.67 \pm 2.31^{b}$ & 0.012 \\
\hline \multirow[t]{3}{*}{234.30} & 2 & $70.37 \pm 1.87^{b}$ & $91.32 \pm 3.69^{a}$ & $93.00 \pm 2.00^{a}$ & 0.000 \\
\hline & 4 & $70.37 \pm 1.86^{b}$ & $91.32 \pm 3.68^{a}$ & $93.00 \pm 2.00^{a}$ & 0.005 \\
\hline & 6 & $76.88 \pm 3.22^{b}$ & $94.16 \pm 2.44^{\mathrm{a}}$ & $95.00 \pm 1.73^{a}$ & 0.000 \\
\hline \multirow[t]{3}{*}{292.88} & 2 & $44.33 \pm 9.19^{b}$ & $94.23 \pm 1.31^{\mathrm{a}}$ & $94.67 \pm 1.15^{a}$ & 0.002 \\
\hline & 4 & $59.00 \pm 2.78^{b}$ & $94.31 \pm 2.64^{\mathrm{a}}$ & $95.67 \pm 1.53^{a}$ & 0.000 \\
\hline & 6 & $66.36 \pm 25.1^{\mathrm{a}}$ & $94.87 \pm 1.06^{b}$ & $96.00 \pm 1.00^{b}$ & 0.038 \\
\hline \multirow[t]{3}{*}{351.45} & 2 & $12.71 \pm 7.99$ & $13.33 \pm 10.25$ & $18.00 \pm 6.93$ & 0.538 \\
\hline & 4 & $17.60 \pm 4.91$ & $18.68 \pm 3.91$ & $22.00 \pm 3.22$ & 0.269 \\
\hline & 6 & $26.43 \pm 3.95$ & $25.29 \pm 5.03$ & $19.00 \pm 3.52$ & 0.482 \\
\hline
\end{tabular}

a,b: Values in row with different letters are significantly different $(p<0.05)$. 


\subsection{Indole Removal at Different Initial Concentrations}

The culture media inoculated with bacterial strains degraded indole under aerobic conditions when the initial concentration was ranging from $0.5-3.0 \mathrm{mM}(58.58-351.45 \mathrm{mg} / \mathrm{L})$. There was no degradation when the initial concentration of indole was $>300 \mathrm{mg} / \mathrm{L}$ (Figures 1-3) and also no bacterial colony formation on the nutrient agar plates. Indole degradation resulting from the mix of two strains was similar with that of TAT1-6A (Figures 2 and 3). No appreciable loss of indole was observed in the sterile controls. Indole degradation and proliferation of bacterial strains were inhibited when indole concentration was $>351.45 \mathrm{mg} / \mathrm{L}$ owing to the toxicity of the substrate.

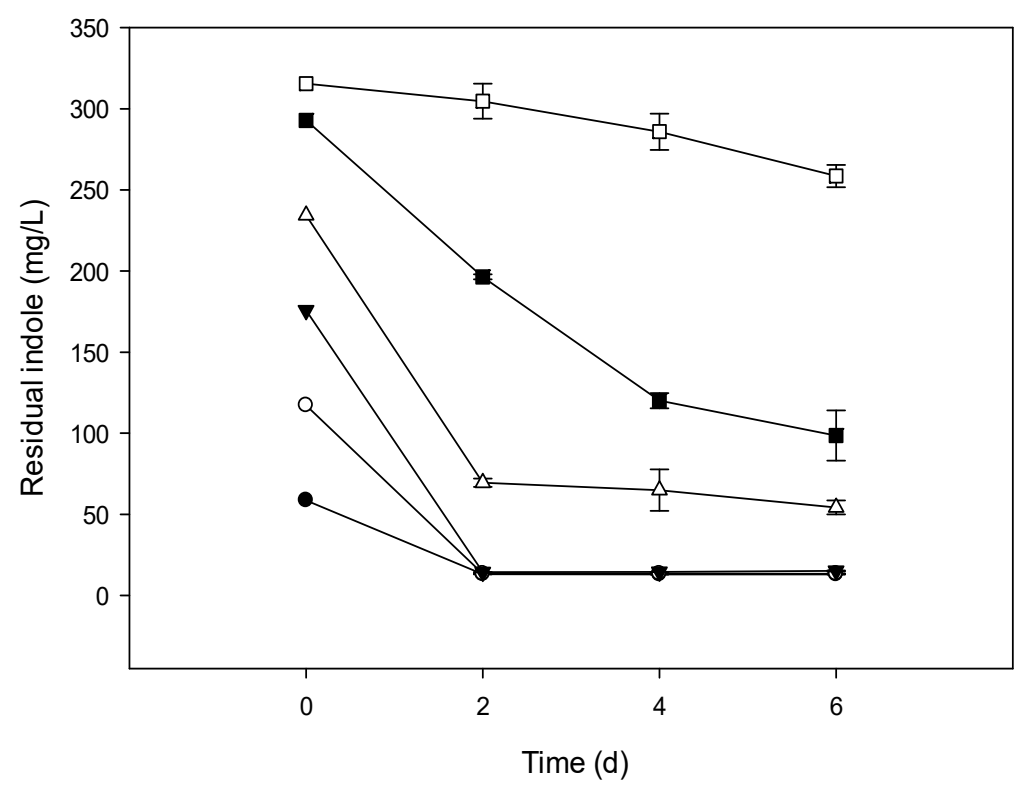

Figure 1. Indole removal capability of NTA1-2A strain at different initial concentrations (mg/L). Symbols: Solid circle, 58.58; open circle, 117.15; solid triangle, 175.73; open triangle, 234.30; solid square, 292.87; open square, 351.45 ; error bars, mean \pm Standard Error (SE) of three replicates at $31^{\circ} \mathrm{C}$ and $\mathrm{pH} 6$.

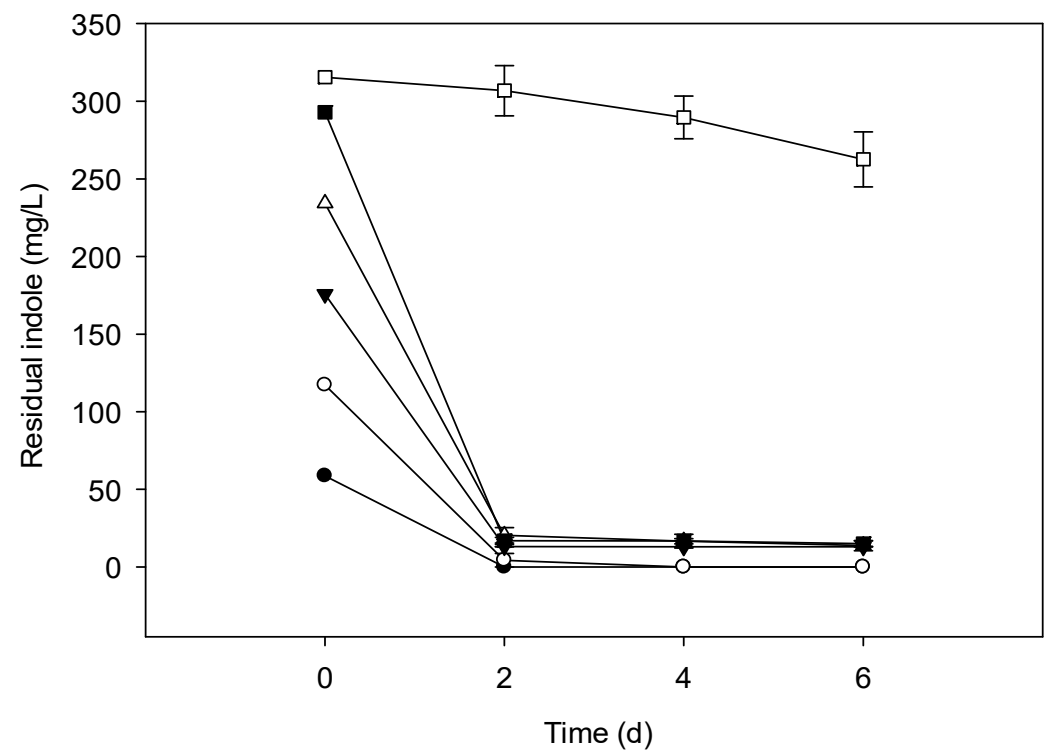

Figure 2. Indole removal capability of TAT1-6A strain at different initial concentrations (mg/L). Symbols: Solid circle, 58.58; open circle, 117.15; solid triangle, 175.73; open triangle, 234.30; solid square, 292.87; open square, 351.45; error bars, mean $\pm \mathrm{SE}$ of three replicates at $31^{\circ} \mathrm{C}$ and $\mathrm{pH} 6$. 


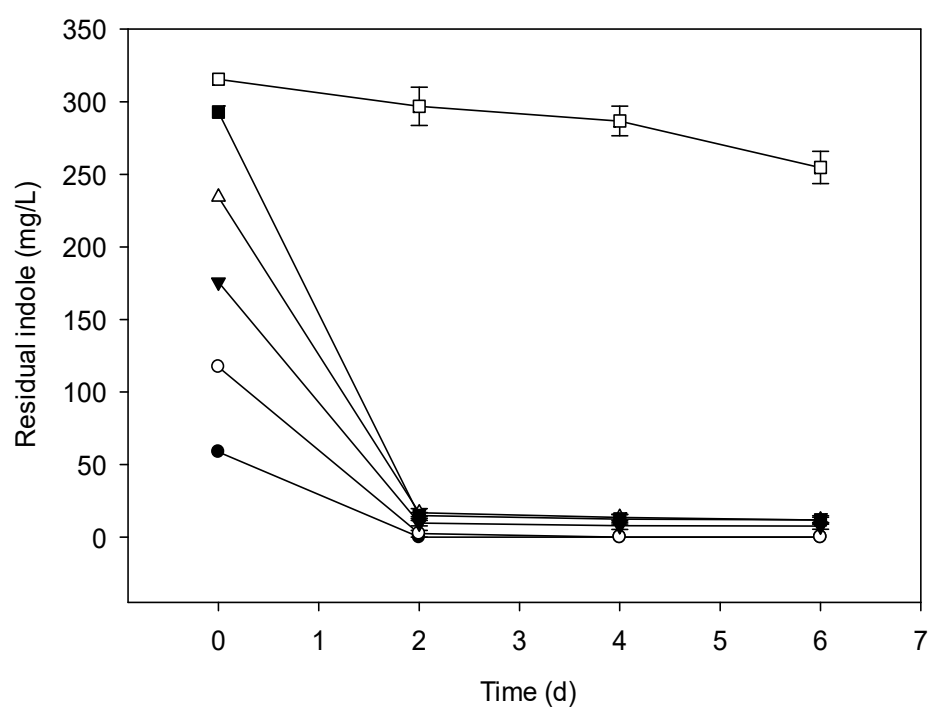

Figure 3. Indole removal capability of a mix of two strains (NTA1-2A and TAT1-6A) at different initial concentrations (mg/L). Symbols: Solid circle, 58.58; open circle, 117.15; solid triangle, 175.73; open triangle, 234.30; solid square, 292.87; open square, 351.45; error bars, mean \pm SE of three replicates at $31^{\circ} \mathrm{C}$ and $\mathrm{pH} 6$.

\subsection{Factors Affecting Indole Degradation}

\subsubsection{Effect of Temperature and $\mathrm{pH}$}

MSM medium amended with $117.15 \mathrm{mg} / \mathrm{L}(1.0 \mathrm{mM})$ of indole was inoculated with $100 \mu \mathrm{L}$ inoculants and incubated for $96 \mathrm{~h}$ at temperatures of $25,28,31,34$, and $37^{\circ} \mathrm{C}$, and $5,6,7,8$, and $9 \mathrm{pH}$ values.

Effect of temperature: The percent degradation efficiency of indole increased as the incubation temperature rose from $25^{\circ} \mathrm{C}$ to $31^{\circ} \mathrm{C}$. Peak degradation efficiency was observed at $31^{\circ} \mathrm{C}$ and declined as temperature increased to $37^{\circ} \mathrm{C}$ (Figure 4).

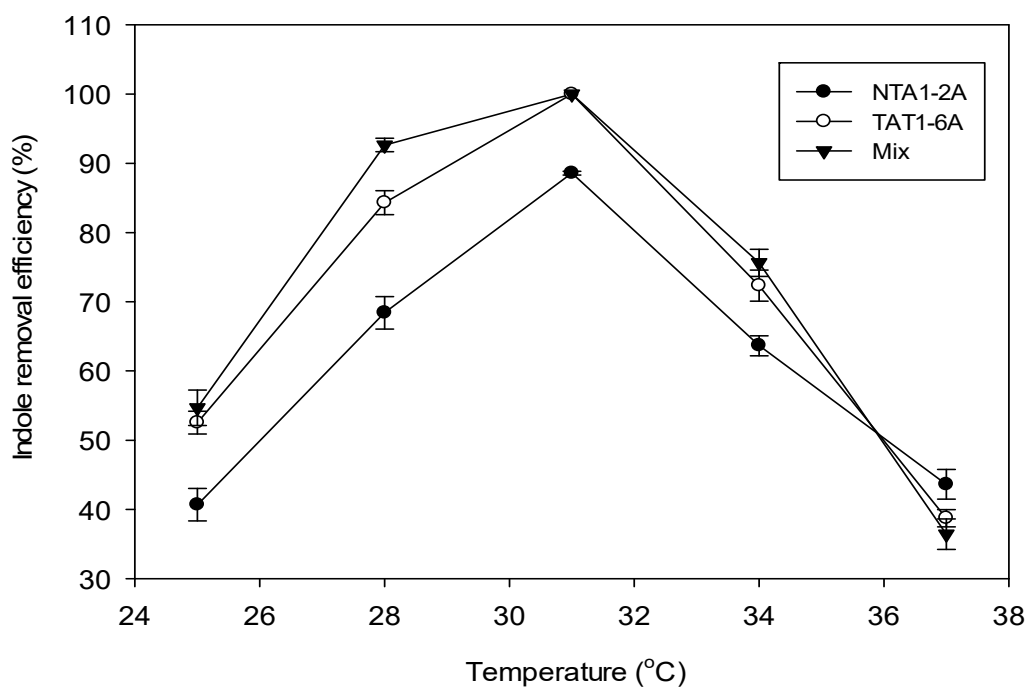

Figure 4. Effect of temperature on indole removal efficiency (\%) at $\mathrm{pH} 6$ and $117.15 \mathrm{mg} / \mathrm{L}(1.0 \mathrm{mM})$ of indole concentration incubated for 96 h. Error bars: Mean \pm SE of three replicates.

Effect of $\mathrm{pH}$ : Indole degradation using the two strains was also affected by the $\mathrm{pH}$ of the culture media solutions. Both strains and the mix exhibited maximum indole degradation efficiency (\%) at $\mathrm{pH}$ 6. Strain TAT1-6A and the mix showed increased indole degradation efficiency between $\mathrm{pH} 6$ and 7 (Figure 5). 


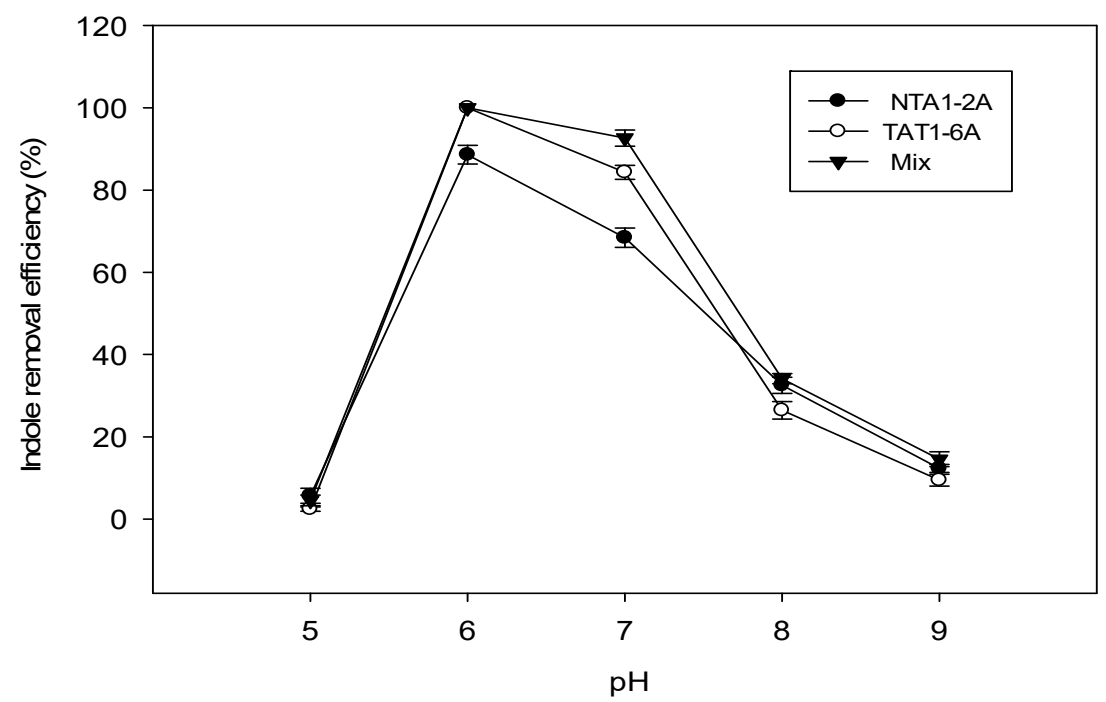

Figure 5. Effect of $\mathrm{pH}$ on indole removal efficiency (\%) at $31^{\circ} \mathrm{C}$ and $117.15 \mathrm{mg} / \mathrm{L}(1.0 \mathrm{mM})$ of indole concentration incubated for 96 h. Error bars: Mean \pm SE of three replicates.

\subsubsection{Effect of Indole on Bacterial Growth}

Indolic compounds have an inhibitory effect on the proliferation of microorganisms. In our study, different concentrations of indole were used to demonstrate its effect on the growth of NTA1-2A and TAT1-6A strains (Figure 6).
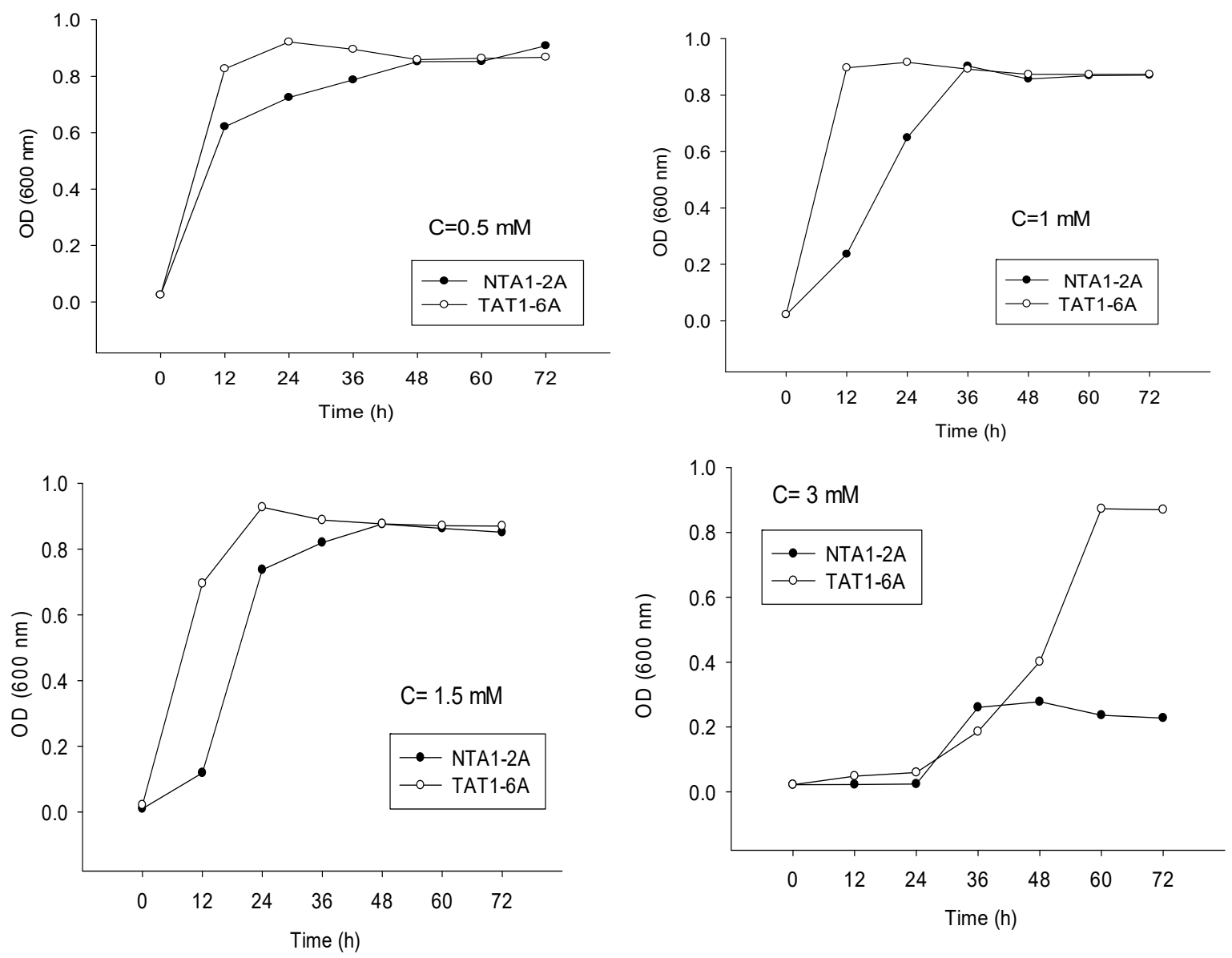

Figure 6. Proliferation of Strains NAT1-2A and TAT1-6A at concentrations (C) of $0.5 \mathrm{mM}$ (58.58 mg/L); $1.0 \mathrm{mM}(117.15 \mathrm{mg} / \mathrm{L}) ; 1.5 \mathrm{mM}(175.73 \mathrm{mg} / \mathrm{L})$ and $3.0 \mathrm{mM}(351.45 \mathrm{mg} / \mathrm{L})$ of indole for $72 \mathrm{~h}$. 


\subsection{Enzymatic Activity of Indole Metabolism}

The enzyme activities of crude extracts obtained from cultures of NTA1-2A and TAT1-6A strains were measured. Indole concentration of $120 \mathrm{mg} / \mathrm{L}$ was used to test the activity. Supernatant fluid of culture media of both NTA1-2A and TAT1-6A removed $96.34 \%$ and $97.71 \%$ of indole, respectively (Figure 7) within $48 \mathrm{~h}$. In the control group, there was no appreciable change in indole concentration. The result directly indicated that these strains have the potential to degrade indole.

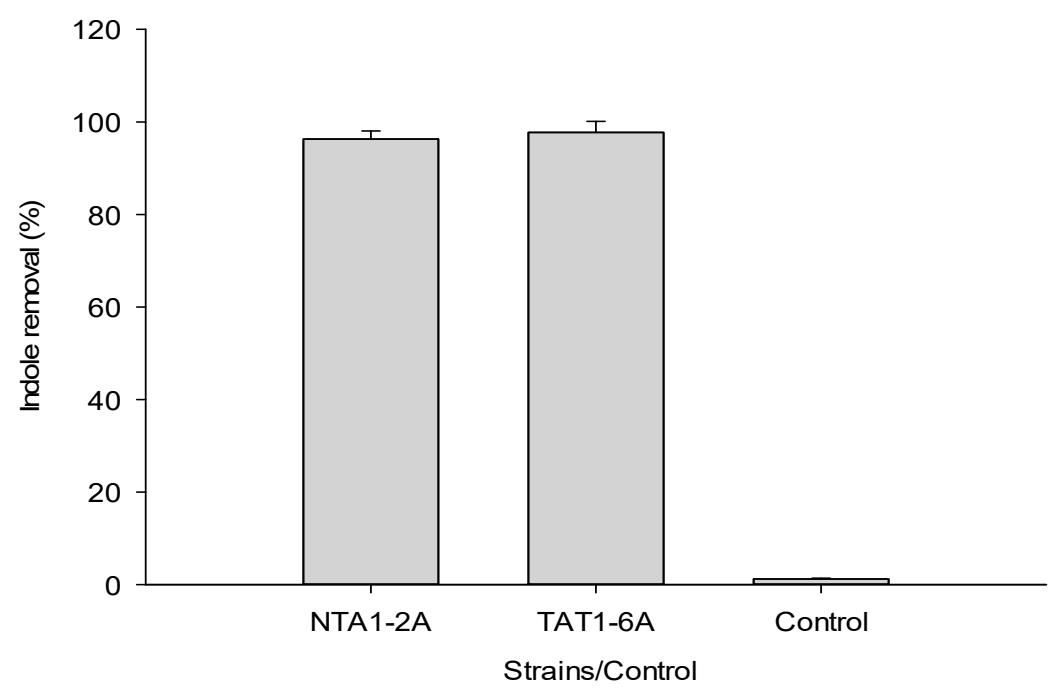

Figure 7. Indole removal test by extract or supernatant fluid obtained from medium cultures of NTA1-2A and TAT1-6A. Error bars: Mean \pm SE of three replicates.

\subsection{Indole Removal from Poultry Manure}

This experiment was designed to test the practical application and potential of the strains NTA1-2A and TAT1-6A to remove malodorous indolic compounds from poultry manure. The bacterial strains were used to ferment the manure for 8 days. The pretreatment indole content of the manure was determined and used as reference (which was $6.29 \pm 0.44 \mathrm{mg} / \mathrm{kg}$ of three replicates) to analyze the removal efficiency of the strains. The NTA1-2A, TAT1-6A, and the mix of the strains removal efficacy (Table 2) of indole from the manure was $78.67 \%, 83.28 \%$, and $83.70 \%$, respectively in 8 days. The strains showed significant removal efficiency $(p<0.05)$ compared with the control group but no significant difference between the two strains and the mix $(p>0.05)$.

Table 2. Indole removal efficiency of NTA1-2A, TAT1-6A and the mix of strains from poultry manure.

Data values are mean \pm SD of triplicate assays.

\begin{tabular}{cccccc}
\hline \multicolumn{5}{c}{ Indole Removal Efficiency from Chicken Manure (\%) } \\
\hline Time (d) & NTA1-2A & TAT1-6A & Mix of Strains & Control & $p$-Value \\
\hline 2 & $58.73 \pm 5.81^{\mathrm{ab}}$ & $67.65 \pm 4.55^{\mathrm{a}}$ & $69.55 \pm 1.57^{\mathrm{a}}$ & $43.55 \pm 6.84^{\mathrm{b}}$ & 0.025 \\
4 & $72.38 \pm 3.66^{\mathrm{b}}$ & $78.35 \pm 2.87^{\mathrm{ab}}$ & $85.64 \pm 1.59^{\mathrm{a}}$ & $50.91 \pm 5.44^{\mathrm{c}}$ & 0.001 \\
6 & $74.49 \pm 2.63^{\mathrm{a}}$ & $80.00 \pm 2.06^{\mathrm{a}}$ & $78.62 \pm 3.10^{\mathrm{a}}$ & $55.03 \pm 4.50^{\mathrm{b}}$ & 0.002 \\
8 & $78.67 \pm 1.70^{\mathrm{a}}$ & $83.28 \pm 1.33^{\mathrm{a}}$ & $83.70 \pm 1.02^{\mathrm{a}}$ & $54.57 \pm 2.81^{\mathrm{b}}$ & 0.000 \\
\hline
\end{tabular}

$\mathrm{a}, \mathrm{b}, \mathrm{c}$ : Values in row with different letters are significantly different $(p<0.05)$.

\section{Discussion}

Indole biodegradation was studied in the last two decades using bacteria from different sources; marine sediments $[13,20]$, sewage plant $[49,50]$, and evaluated their degradation potential. For instance, Bak and Widdel [1] studied Desulfobacterium indolicum gen. nov., sp. nov. anaerobically degrading 
$1.5 \mathrm{mM}$ of indole added to sulfate-rich marine mud or sulfate-free sewage digester sludge within one week. Yin et al. [20] reported Pseudomonas aeruginosa Gs degrading indole completely in four days when the concentration was $3.0 \mathrm{mM}$. Recently, Acinetobacter strains named NTA1-2A and TAT1-6A obtained from 3-methylindole acclimated samples [47] were used to degrade indole. The strains also utilized indole as their sole carbon source and efficiently removed $<300 \mathrm{mg} / \mathrm{L}$ indole within six days when cultured in simple mineral salt medium at $31^{\circ} \mathrm{C}$ and $\mathrm{pH}$ 6. Cupriavidus strains named IDO and SHE also utilized indole as their sole carbon source and efficiently removed $100 \mathrm{mg} / \mathrm{L}$ indole within a day [9,51]. Lin et al. [52] reported that strain Acinetobacter baumannii ATCC19606 could detoxify indole by converting it to non-toxic indigo. Sadauskas et al. [41] also investigated Acinetobacter sp. O153 which degraded indole via indole-2,3-dihydrodiol, 3-hydroxyindolin-2-one. In another study, Acinetobacter sp. JW and Burkholderia sp. IDO3 exhibited degradation ability of $100 \mathrm{mg} / \mathrm{L}$ indole within 14 and $20 \mathrm{~h}$, respectively [42,43]. Yan et al. [44] reported that Acinetobacter pittii L1 can completely remove $400 \mathrm{mg} / \mathrm{L}$ indole within $48 \mathrm{~h}$. There are also other indole-degrading strains such as Arthrobacter sp., Alcaligenes sp., Burkholderia unamae, Pseudomonas aeruginosa, and Agrobacterium tumefaciens reported [53-56]. The indole biodegradation results obtained in the current study by strain TAT1-6A is similar with Pseudomonas aeruginosa $(300 \mathrm{mg} / \mathrm{L})$ reported by Yin et al. [20]. NTA1-2A indole removal ability was low when compared with TAT1-6A, however better than Pseudomonas sp. ST-200 (100 mg/L) [28] and Asprigillus niger $(180 \mathrm{mg} / \mathrm{L})$ [2].

Different environmental factors are responsible for the metabolism of indole. Madsen et al. [24] reported that $\mathrm{pH}$, temperature, and concentration of sewage sludge influence indole metabolism under anaerobic conditions. Yin et al. [20] discovered $\mathrm{pH}$ and salinity of media solution influences the degradation activity and proliferation of Pseudomonas aeruginosa Gs isolated from mangrove sediment. In our experiment, temperature and $\mathrm{pH}$ highly affected the degradation of indole (Figures 4 and 5) and our two strains showed better indole removal ability at $28-31^{\circ} \mathrm{C}$ and $\mathrm{pH} 6-7$ which is similar with Acinetobacter sp. JW [43]. In Burkholderia sp. IDO3, Ma et al. [42] reported indole degradation performance maintained under conditions of $\mathrm{pH} 4.0-9.0$ and temperature $25-35^{\circ} \mathrm{C}$ which is a broad range compared with NTA1-2A and TAT1-6A strains.

Studies revealed that indole has microbial specific inhibitory effect on their growth [57-59]. Yang et al. [60] reported indole and its derivatives inhibit the growth of microorganisms and biofilm formation. For microorganisms, indole can induce bacterial membrane and oxidant toxicity, prevent cell division by modulating cell membrane potential, inhibit adenosine triphosphate production and protein folding, and cause reparable DNA damage $[15,55,61,62]$. Due to the toxic nature of indolic compounds to microorganisms, their concentrations were kept low when supplied to culture medium [24,25,48,63,64]. Aromatic compounds are generally lipophilic [28], but it has been observed that Pseudomonas sp. ST-200 can grow at a high concentration of indole when an organic solvent-water system consisting of two phases is used to avoid the toxicity effects. In another study, Yin et al. [20] reported that higher concentrations of indole is toxic and inhibits bacterial growth. Similarly, at a concentration $>300 \mathrm{mg} / \mathrm{L}$, growth of NTA1-2A and TAT1-6A strains were inhibited and no colony formed on the agar plate. Indole also decreases cell growth of a fungus Aspergillus niger [2].

Bacteria play an important role in aerobic and anaerobic fermentation of manure to release nutrients and transform harmful organic compounds. Aerobic fermentation is one of the most effective ways of treating manure harmlessly and resourcefully $[65,66]$. Animal manure has become a major source of ecological and environmental pollution [67] which is not only harmful for the environment and human health, but also influences the sustainable development of poultry and livestock industries. NTA1-2A and TAT1-6A strains are non-pathogenic, ubiquitous microbes of promising candidates capable of removing $78.67 \%$ and $83.28 \%$ indole, respectively and $83.70 \%$ in a mix from poultry manure in eight days.

Many bacterial strains do have the potential of removing pollutants like indolic compounds and others from the environment under different conditions via the production of intracellular or extracellular enzymes. For example, many non-indole producing bacteria encode enzymes that can 
degrade indole and produce indole derivatives [68,69]. Maeng et al. [35] reported n-alkane degradation by Acinetobacter sp. attacked by a dioxygenase enzyme. Carr et al. [70] revealed methyl oxidation of 3-methylindole by cytochrome P450 enzymes. Nakai et al. [4] reported supernatant fluids of culture extracted from 3-methylindole degrading isolates showed 3-methylindole degradation activities. In this study, the supernatant fluid extract obtained from the two strains' culture medium completely removed $120 \mathrm{mg} / \mathrm{L}$ of indole within $48 \mathrm{~h}$. This is a clear indication that the strains have a promising potential of degrading indolic compounds which are challenging the rapidly expanding intensive poultry and livestock industries.

\section{Conclusions}

Two Acinetobacter strains, Acinetobacter toweneri NTA1-2A and Acinetobacter guillouiae TAT1-6A were tested for in vitro and in vivo indole degradation potential. The strains degraded initial concentrations of indole ranging from 58.58 to $300 \mathrm{mg} / \mathrm{L}$. The degradation rate was $>65 \%$ in 6 days in both strains when the initial concentration was less than $300 \mathrm{mg} / \mathrm{L}$. The experiment revealed the two strains have the capability of removing indole from poultry manure. We conclude that the outstanding indole removal capacity make the two strains promising candidates to reduce noxious fecal odorants due to indolic compounds in the poultry, livestock industries and other wastewater treatment processes. Future studies should focus on the biochemical and molecular basis of indole degradation by the two strains.

Author Contributions: Conceptualization, data curation, methodology, investigation, formal analysis, and original draft preparation, T.A.T.; review and editing, G.H.L. and T.A.T.; visualization, supervision, project administration, resources, G.H.L.

Funding: This research was supported by Beijing Innovation Consortium of the Poultry-industry Research System of China (BAIC04-2019).

Conflicts of Interest: The authors declare no conflict of interest.

\section{References}

1. Bak, F.; Widdel, F. Anaerobic degradation of indolic compounds by sulfate-reducing enrichment cultures, and description of Desulfobacterium indolicum gen. nov. sp. nov. Arch. Microbiol. 1986, 146, 170-176. [CrossRef]

2. Kamatht, A.V.; Vaidyanathan, C.S. New Pathway for the Biodegradation of Indole in Aspergillus niger. Appl. Environ. Microbiol. 1990, 56, 275-280.

3. Kohda, C.; Ando, T.; Nakai, Y. Isolation and characterization of anaerobic indole-and skatole-degrading bacteria from composting animal wastes. J. Gen. Appl. Microbiol. 1997, 43, 249-255. [CrossRef] [PubMed]

4. Nakai, Y.; Niino, T.; Ando, T.; Kohda, C. Microorganisms aerobically degrading skatole or indole in composting processes. Anim. Sci. J. 1999, 70, 32-37. [CrossRef]

5. Loughrin, J.H.; Lovanh, N.; Mahmood, R. Equilibrium sampling used to monitor malodors in a Swine waste lagoon. J. Environ. Qual. 2008, 37, 1-6. [CrossRef] [PubMed]

6. Ochiai, M.; Wakabayashi, K.; Sugimura, T.; Nagao, M. Mutagenicities of indole and 30 derivatives after nitrite treatment. Mutat. Res. 1986, 172, 189-197. [CrossRef]

7. Novotny, M.; Strand, J.W.; Smith, S.L.; Wiesler, D.; Schwende, F.J. Compositional studies of coal tar by capillary gas chromatographymass spectrometry. Fuel 1981, 60, 213-220. [CrossRef]

8. Paudler, W.W.; Cheplen, M. Nitrogen bases in solvent-refined coal. Fuel 1979, 58, 775-778. [CrossRef]

9. Qu, Y.; Shen, E.; Ma, Q.; Zhang, Z.; Liu, Z.; Shen, W.; Wang, J.; Li, D.; Li, H.; Zhou, J. Biodegradation of indole by a newly isolated Cupriavidus sp. SHE. J. Environ. Sci. 2015, 34, 126-132. [CrossRef]

10. De la Torre, A.; Jimenez, J.A.; Carballo, M.; Fernandez, C. Ecotoxicological evaluation of pig slurry. Chemosphere 2000, 41, 1629-1635. [CrossRef]

11. Loughrin, J.H.; Szogi, A.A.; Vanotti, M.B. Reduction of malodorous compounds from a treated swine anaerobic lagoon. J. Environ. Qual. 2006, 35, 194-199. [CrossRef] 
12. Chen, L.; Hoff, S.J.; Koziel, J.A.; Cai, L.; Zelle, B.; Sun, G. Performance evaluation of a wood-chip based biofilter using solid-phase microextraction and gas chromatography-mass spectroscopy-olfactometry. Bioresour. Technol. 2008, 99, 7767-7780. [CrossRef] [PubMed]

13. Gu, J.; Fan, Y.; Shi, H. Relationship between structures of substituted indolic compounds and their degradation by marine anaerobic microorganisms. Mar. Pollut. Bull. 2002, 45, 379-384. [CrossRef]

14. Kamath, A.V.; Vaidyanathan, C. Biodegradation of indoles. J. Indian Inst. Sci. 2013, 71, 1-24.

15. Garbe, T.R.; Kobayashi, M.; Yukawa, H. Indole-inducible proteins in bacteria suggest membrane and oxidant toxicity. Arch. Microbiol. 2000, 173, 78-82. [CrossRef]

16. Fetzner, S. Bacterial degradation of pyridine, indole, quinoline, and their derivatives under different redox conditions. Appl. Microbiol. Biotechnol. 1998, 49, 237-250. [CrossRef]

17. Berry, D.F.; Madsen, E.L.; Bollag, J. Conversion of Indole to Oxindole under Methanogenic Conditions. Appl. Environ. Microbiol. 1987, 53, 180-182. [PubMed]

18. Arora, P.K.; Bae, H. Identification of new metabolites of bacterial transformation of indole by gas chromatography-mass spectrometry and high performance liquid chromatography. Int. J. Anal. Chem. 2014, 2014. [CrossRef] [PubMed]

19. Sakamoto, Y.; Uchida, M.; Ichihara, K. The bacterial decomposition of indole (I) studies on its metabolic pathway by successive adaptation. Med. J. Osaka Univ. 1953, 3, 477-486.

20. Yin, B.; Gu, J.; Wan, N. Degradation of indole by enrichment culture and Pseudomonas aeruginosa Gs isolated from mangrove sediment. Int. Biodeterior. Biodegrad. 2005, 56, 243-248. [CrossRef]

21. Arora, P.K.; Dhar, K.; García, R.A.V.; Sharma, A. Biotransformation of Indole to 3 Methylindole by Lysinibacillus xylanilyticus Strain MA. J. Chem. 2015. [CrossRef]

22. Wang, Y.T.; Suidan, M.T.; Pfeffer, J.T. Anaerobic biodegradation of indole to methane. Appl. Environ. Microbiol. 1984, 48, 1058-1060.

23. Berry, D.F.; Francis, A.J.; Bollagi, J.M. Microbial Metabolism of Homocyclic and Heterocyclic Aromatic Compounds under Anaerobic Conditions. Microb. Rev. 1987, 51, 43-59.

24. Madsen, E.L.; Francis, A.J.; Bollag, J.M. Environmental factors affecting indole metabolism under anaerobic conditions. Appl. Eenviron. Mmicrobiol. 1988, 54, 74-78.

25. Madsen, E.L.; Bollag, J.M. Pathway of indole metabolism by a denitrifying microbial community. Arch. Microbiol. 1988, 151, 71-76. [CrossRef]

26. Gu, J.D.; Berry, D.F. Degradation of Substituted Indoles by an Indole-Degrading Methanogenic Consortium. Appl. Environ. Microbiol. 1991, 57, 2622-2627.

27. Gu, J.D.; Berry, D.F. Metabolism of 3-methylindole by a methanogenic consortium. Appl. Environ. Microbiol. 1992, 58, 2667-2669. [PubMed]

28. Doukyu, N.; Anon, R. Biodegradation of indole at high concentration by persolvent fermentation with Pseudomonas sp. ST-200. Extremophiles 1997, 1, 100-105. [CrossRef] [PubMed]

29. Fukuoka, K.; Tanaka, Y.; Ozeki, Y.; Kanaly, R.A. Biotransformation of indole by Cupriavidus sp. strain KK10 proceeds through N-heterocyclic- and carbocyclic-aromatic ring cleavage and production of indigoids. Int. Biodeterior. Biodegrad. 2015, 97, 13-24. [CrossRef]

30. Allen, C.C.R.; Boyd, C.; Larkin, M.J.; Reid, K.A.; Sharma, N.D.; Wilson, K. Metabolism of Naphthalene, 1-Naphthol, Indene, and Indole by Rhodococcus sp. Strain NCIMB 12038. Appl. Environ. Microbiol. 1997, 63, 151-155.

31. Han, X.; Wang, W.; Xiao, X. Microbial biosynthesis and biotransformation of indigo and indigo-like pigments. Chin. J. Biotechnol. 2008, 24, 921-926. [CrossRef]

32. Wang, J.; Zhang, X.; Fan, J.; Zhang, Z.; Ma, Q.; Peng, X. Indigoids biosynthesis from indole by two phenol-degrading strains, Pseudomonas sp. PI1 and Acinetobacter sp. PI2. Appl. Biochem. Biotechnol. 2015, 176, 1263-1276. [CrossRef]

33. Qu, Y.; Xu, B.; Zhang, X.; Ma, Q.; Zhou, H.; Kong, C.; Zhang, Z.; Zhou, J. Biotransformation of indole by whole cells of recombinant biphenyl dioxygenase and biphenyl-2, 3-dihydrodiol-2, 3-dehydrogenase. Biochem. Eng. J. 2013, 72, 54-60. [CrossRef]

34. Efeovbokhan, V.E.; Hymore, F.K.; Ayoola, A.A.; Adeeyo, O.A. Comparison of aerobic and anaerobic bioremediation of polluted water samples. Am. Int. J. Contemp. Res. 2014, 4, 120-126. 
35. Maeng, J.H.O.; Sakai, Y.; Ttani, Y.; Kato, N. Isolation and Characterization of a Novel Oxygenase that Catalyzes the first step of n-Alkane oxidation in Acinetobacter sp. Strain M-1. J. Bacteriol. 1996, 178, 3695-3700. [CrossRef] [PubMed]

36. Throne-Holst, M.; Wentzel, A.; Ellingsen, T.E.; Kotlar, H.K.; Zotchev, S.B. Identification of Novel Genes Involved in Long-Chain n-Alkane Degradation by Acinetobacter sp. Strain DSM 17874. Appl. Eenviron. Microbiol. 2007, 73, 3327-3332. [CrossRef] [PubMed]

37. Kim, M.H.; Hao, O.J. Cometabolic degradation of chlorophenols by Acinetobacter species. Water Resour. 1999, 33, 562-574. [CrossRef]

38. Yu, X.Q.; Elmerich, A.B.C.; Lin, M. Diversity of degradation pathways of some aromatic compounds by phenotype and genotype testing in Acinetobacter strains. World J. Microbiol. Biotechnol. 2004, 20, 623-627. [CrossRef]

39. Liu, Y.J.; Kusckh, P.; Zhang, A.N.; Wang, X.C. Characterization of phenol degradation by Acinetobacter sp. XA05 and Sphingomonas sp. FG03. Chem. Ecol. 2009, 25, 107-117. [CrossRef]

40. Shamaan, A. Isolation, Identification and Characterization of Elevated Phenol Degrading Acinetobacter sp. Strain AQ5NOL. Aust. J. Basic Appl. Sci. 2011, 5, 1035-1045.

41. Sadauskas, M.; Vaitekunas, J.; Gasparaviciute, R.; Meškys, R. Indole biodegradation in Acinetobacter sp. strain O153, genetic and biochemical characterization. Appl. Environ. Microbiol. 2017, 83. [CrossRef] [PubMed]

42. Ma, Q.; Liu, Z.; Yang, B.; Dai, C.; Qu, Y. Characterization and functional gene analysis of a newly isolated indole-degrading bacterium Burkholderia sp. IDO3. J. Hazard. Mater. 2019, 367, 144-151. [CrossRef] [PubMed]

43. Zhang, X.; Jing, J.; Zhang, L.; Song, Z.; Zhou, H.; Wu, M.; Qu, Y.; Liu, L. Biodegradation characteristics and genomic functional analysis of indole-degrading bacterial strain Acinetobacter sp. JW. J. Chem. Technol. Biotechnol. 2018. [CrossRef]

44. Yang, Z.; Zhou, J.; Xu, Y.; Zhang, Y.; Luo, H.; Chang, K.; Wang, Y. Analysis of the metabolites of indole degraded by an isolated Acinetobacter pittii L1. BioMed Res. Int. 2017. [CrossRef] [PubMed]

45. Li, Y.; Gu, G.; Zhao, J.; Yu, H. Anoxic degradation of nitrogenous heterocyclic compounds by acclimated activated sludge. Process Biochem. 2001, 37, 81-86. [CrossRef]

46. Katapodis, P.; Moukouli, M.; Christakopoulos, P. Biodegradation of indole at high concentration by persolvent fermentation with the thermophilic fungus Sporotrichum thermophile. Int. Biodeterior. Biodegrad. 2007, 60, 267-272. [CrossRef]

47. Tesso, T.A.; Zheng, A.; Cai, H.; Liu, G. Isolation and characterization of two Acinetobacter species able to degrade 3-methylindole. PLoS ONE 2019, 14, e0211275. [CrossRef] [PubMed]

48. Yin, B.; Gu, J. Aerobic Degradation of 3-Methylindole by Pseudomonas aeruginosa Gs Isolated from Mangrove Sediment. Hum. Ecol. Risk Assess. 2006, 12, 248-258. [CrossRef]

49. Li, P.; Tong, L.; Liu, K.; Wang, Y.; Wang, Y. Indole degrading of ammonia oxidizing bacteria isolated from swine wastewater treatment system. Water Sci. Technol. 2009, 59, 2405-2410. [CrossRef]

50. Shanker, R.A.B.; Bollag, J.M. Transformation of Indole by Methanogenic and Sulfate-Reducing Microorganisms Isolated from Digested Sludge. Microb. Ecol. 1990, 20, 171-183. [CrossRef]

51. Ma, Q.; Qu, Y.; Zhang, X.; Liu, Z.; Li, H.; Zhang, Z.; Wang, J.; Shen, W.; Zhou, J. Systematic investigation and microbial community profile of indole degradation processes in two aerobic activated sludge systems. Sci. Rep. 2015, 5, 17674. [CrossRef]

52. Lin, G.H.; Chen, H.P.; Shu, H.Y. Detoxification of indole by an indole-induced flavoprotein oxygenase from Acinetobacter baumannii. PLoS ONE 2015, 10, e0138798. [CrossRef] [PubMed]

53. Lee, J.; Attila, C.; Cirillo, S.L.; Cirillo, J.D.; Wood, T.K. Indole and 7-hydroxyindole diminish Pseudomonas aeruginosa virulence. Microb. Biotechnol. 2009, 2, 75-90. [CrossRef] [PubMed]

54. Lee, J.H.; Wood, T.K.; Lee, J. Roles of indole as an interspecies and interkingdom signaling molecule. Trends Microbiol. 2015, 23, 707-718. [CrossRef] [PubMed]

55. Kim, D.; Rahman, A.; Sitepu, I.R.; Hashidoko, Y. Accelerated degradation of exogenous indole by Burkholderia unamae strain CK43B exposed to pyrogallol-type polyphenols. Biosci. Biotechnol. Biochem. 2013, 77, 1722-1727. [CrossRef] [PubMed]

56. Arora, P.K.; Sharma, A.; Bae, H. Microbial Degradation of Indole and Its Derivatives. J. Chem. 2015, 2015. [CrossRef]

57. Hu, M.; Zhang, C.; Mu, Y. Indole Affects Biofilm Formation in Bacteria. Indian J. Microbiol. 2011, 50, 362-368. [CrossRef] 
58. Mueller, R.S.; Beyhan, S.; Saini, S.G.; Yildiz, F.H.; Bartlett, D.H. Indole Acts as an Extracellular Cue Regulating Gene Expression. J. Bacteriol. 2009, 191, 3504-3516. [CrossRef]

59. Yildiz, F.H.; Visick, K.L. Vibrio biofilms: So much the same yet so different. Trends Microbiol. 2009, 17, 109-118. [CrossRef]

60. Yang, C.; Yu, Y.; Sun, W.; Xia, C. Indole derivatives inhibited the formation of bacterial biofilm and modulated Ca $2+$ efflux in diatom. Mar. Pollut. Bull. 2014, 88, 62-69. [CrossRef]

61. Ma, Q.; Zhang, X.; Qu, Y. Biodegradation and biotransformation of indole: Advances and perspectives. Front. Microbiol. 2018, 9. [CrossRef]

62. Chimerel, C.; Field, C.M.; Piñero-Fernandez, S.; Keyser, U.F.; Summers, D.K. Indole prevents Escherichia coli cell division by modulating membrane potential. Biochim. Biophys. Acta 2013, 1818, 1590-1594. [CrossRef] [PubMed]

63. Mermod, N.; Harayama, S.; Timmis, K.N. New route to bacterial production of indigo. Bio/Technology 1986, 4, 321. [CrossRef]

64. Eaton, R.W.; Chapman, P.J. Formation of indigo and related compounds from indolecarboxylic acids by aromatic acid-degrading bacteria: Chromogenic reactions for cloning genes encoding dioxygenases that acts on aromatic acids. J. Bacteriol. 1995, 177, 6983-6988. [CrossRef]

65. Müller, C.E.; Johansson, M.; Salomonsson, A.C.; Albihn, A. Effect of anaerobic digestion residue vs livestock manure and inorganic fertilizer on the hygienic quality of silage and haylage in bales. Grass Forage Sci. 2013, 69, 74-89. [CrossRef]

66. Elsaidy, N.; Abouelenien, F.; Kirrella, G.A.K. Impact of using raw or fermented manure as fish feed on microbial quality of water and fish. Egypt. J. Aquat. Res. 2015. [CrossRef]

67. Heuer, H.; Schmitt, H.; Smalla, K. Antibiotic resistance gene spread due to manure application on agricultural fields. Curr. Opin. Microbiol. 2011, 14, 236-243. [CrossRef] [PubMed]

68. Rui, L.; Reardon, K.F.; Wood, T.K. Protein engineering of toluene ortho-monooxygenase of Burkholderia cepacia G4 for regiospecific hydroxylation of indole to form various indigoid compounds. Appl. Microbiol. Biotechnol. 2005, 66, 422-429. [CrossRef]

69. Wikoff, W.R.; Anfora, A.T.; Liu, J.; Schultz, P.G.; Lesley, S.A.; Peters, E.C.; Siuzdak, G. Metabolomics analysis reveals large effects of gut microflora on mammalian blood metabolites. Proc. Natl. Acad. Sci. USA 2009, 106, 3698-3703. [CrossRef]

70. Carr, B.A.; Ghazi, S.R.; Dannan, A.; Yost, G.S. Characterization of Pulmonary CYP4B2, Specific Catalyst of Methyl Oxidation of 3-Methylindole. Mol. Pharm. 2003, 63, 1137-1147. [CrossRef] 